This is an author produced version of a paper published in FOREST ECOLOGY \& MANAGEMENT. This paper has been peer-reviewed and is proof-corrected, but does not include the journal pagination.

Citation for the published paper:

Backéus, S., Wikström, P. \& Lämås, T. (2005) A model for regional analysis of carbon sequestration and timber production. Forest Ecology \& Management. Volume: 216 Number: 1-3, pp 28-40. http://dx.doi.org/10.1016/j.foreco.2005.05.059

Access to the published version may require journal subscription. Published with permission from: Elsevier

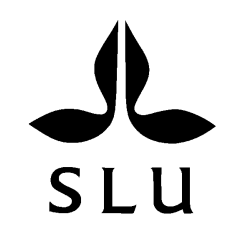

Epsilon Open Archive http://epsilon.slu.se 


\title{
A model for regional analysis of carbon sequestration and timber production
}

\author{
Sofia Backéus, Peder Wikström and Tomas Lämås
}

Dept of Forest Resource Management and Geomatics, SLU (Swedish University of Agricultural Sciences), SE-901

83 Umeå, Sweden

\begin{abstract}
The greenhouse effect is one of our most severe current environmental problems. Forests make up large ecosystems and can play an important role in mitigating the emissions of $\mathrm{CO}_{2}$, the most important greenhouse gas. Different management regimes affect the ability of forests to sequester carbon. It is important to investigate in what way we best can use forests to mitigate the greenhouse effect. It is also important to study what effect different actions, done to increase carbon sequestration, have on other offsets from forestry, such as the harvest level, the availability of forest biofuel and economic factors.

In this study, we present an optimization model for analysis of carbon sequestration in forest biomass and forest products at a local or regional scale. The model consists of an optimizing stand-level simulator, and the solution is found using linear programming. Carbon sequestration was accounted for in terms of carbon price and its value computed as a function of carbon price and the net carbon storage in the forest. The same price was used as a cost for carbon emission originating from deterioration of wood products.

We carried out a case study for a 3.2 million hectare boreal forest region in northern Sweden. The result showed that 1.48-2.05 million tonnes of carbon per year was sequestered in the area, depending on what carbon price was used. We conclude that assigning carbon storage a monetary value and removal of carbon in forest products as a cost, increases carbon sequestration in the forest and decreases harvest levels. The effect was largest in areas with low site-quality classes.
\end{abstract}

Keywords: boreal forest, carbon sequestration, forest management, optimization, single-tree model

\section{Introduction}

The greenhouse effect is one of our most severe current environmental problems. Owing to the amount released, carbon dioxide $\left(\mathrm{CO}_{2}\right)$ is the most important greenhouse gas. The $\mathrm{CO}_{2}$ concentration in the atmosphere has increased by $31 \%$ since $1750 \mathrm{AD}$ and is predicted to increase considerably in the next hundred years. As a consequence is the temperature expected to increase (Anonymous, 2000). 
Vegetation, soil and oceans can act as carbon sinks. As forests make up large ecosystems, with high biomass volumes, they can play an important role in mitigating the emissions of $\mathrm{CO}_{2}$. Therefore, in extensively forested countries, forests can be central to the mitigation of anthropogenic $\mathrm{CO}_{2}$ emissions. We can affect the amount of carbon sequestered in forest vegetation and soil by changing our forest management practices, e.g., by changing rotation lengths or the intensity of thinning operations. Also, indirect effects such as the deposition of nitrogen and sulphur can affect forest growth either in a positive or negative direction and thus affect the potential for carbon sequestration. Another way of utilizing forests for mitigating the increase of atmospheric $\mathrm{CO}_{2}$ is to substitute fossil fuel with forest biomass (forest biofuel).

The forest ecosystem and the greenhouse gas issue have complex interactions and include biological processes and circulation of substances, as well as socioeconomic aspects. Policymaking within this problem area is therefore an intricate matter and has to be supported by information from scientifically based analyses. New models and tools are being developed for this purpose, such as the model CO2FIX (Nabuurs et al., 2002; Masera et al., 2003). Other models, developed for describing forest development in general, can also be used for carbon sequestration analysis; examples are FORSKA (Prentice and Leemans, 1990; Prentice et al., 1993; Lasch et al., 1999; Lasch et al., 2002), FORECAST (Kimmins et al., 1999; Seely et al., 1999; Seely et al., 2002) and CENTURY (Parton et al., 1987; Jiang et al., 2002; Song and Woodcock, 2003).

Analysis of carbon flows and pools in a forest ecosystem can be done at different scales, by different modelling approaches, and can include a smaller or greater number of carbon cycle components. Many studies have been done at a stand level (Karjalainen, 1996b; Liski et al., 2001; Minkkinen et al., 2001; Pussinen et al., 2002; Spinney and Prisley, 2002), often to investigate different management regimes in detail. Studies have also been carried out at a regional level (Hoen and Solberg, 1994; Lasch et al., 1999; Lasch et al., 2002; Song and Woodcock, 2003), for countries (Turner et al., 1995; Karjalainen, 1996a; Krankina et al., 1996; Ågren and Hyvönen, 2003) or even whole continents (Myneni et al., 2001; Cannell, 2003). In modelling the harvest behaviour in carbon studies, mimicking historic levels, keeping an even flow and/or attaining highest possible harvest level are common methods. Another approach is to model the harvest behaviour by using market models (Adams et al., 1999; Sohngen and Sedjo, 2000; Murray et al., 2004).

For the analysis of management at a stand level, imaginary stands are sometimes used. Such analyses can be useful for studying, e.g., effects of shortened or prolonged rotation periods for "typical" stands. Reliable projections for a large area (e.g. region) with a specific age and site class distribution and tree species composition are hard to attain using imaginary stands. Instead, sample-based data are more appropriate. Data from national forest inventories are often good foundations for analysis, such as data from the Swedish National Forest Inventory (NFI) (Ranneby et al., 1987).

In addition to carbon storage in and fluxes related to the forest, the forestry carbon cycle also includes components such as storage in and fluxes from forest soil, storage in forest products and emission originating from deterioration of these products, and emissions from logging and timber transport. Some models are available for carbon stocks and fluxes in forest soil, e.g., the Q-model by Rolff and Ågren (1999). Carbon stored in forest products and emissions from decay or burning of forest products is also part of the forest carbon cycle and is sometimes included in analyses (Masera et al., 2003). Harvest operations and timber transportation are other sources of carbon emissions and are considered by, e.g., Liski et al. (2001).

Trading of $\mathrm{CO}_{2}$ emission permits and taxes on $\mathrm{CO}_{2}$ emissions are established in e.g. EU (Anonymous, 2003). These factors imply a value on carbon sequestration. If carbon sequestration in forests is included in this trade, or some kind of government-sponsored incentive policy is introduced, it will affect forest management. It is shown that adding a value for carbon sequestration extends the forest rotation length; see, for example, Hoen (1994) or van Kooten et al. (1995). The carbon is stored in the forest during the lifetime of the standing forest, in the forest soils and also during the lifetime of the forest products. It is therefore possible to give credit not only for carbon stored in the standing biomass and soil but also for the storage of carbon in forest products. In analyses, the timber values can be included in the same way as in ordinary timber management analyses, and the carbon sequestration can be treated as an extra value (Creedy and Wurzbacher, 2001; Field, 2001). 
Analyses can be based on optimization or elaboration of scenarios using simulation approaches. The latter is appropriate when evaluating a few specific scenarios, such as the effect of rotation period on carbon sequestration or forest-fuel production for a few different silvicultural regimes. When there are explicit goals for the analysis - for example, identifying the maximum value of different outcomes and utilities from a forest-optimization gives the opportunity to explore a much larger number of alternatives than scenario analyses. Hoen and Sohlberg (1994) used an optimising model (LP model I) to analyse the potential for increasing the carbon sequestration in a 575000 ha forest region in Norway. For each stand, a number of different management alternatives were possible. Using the model, they maximize the net present value of timber production $\left(\mathrm{NPV}_{\mathrm{NOK}}\right)$ or the discounted mass of carbon sequestrated $\left(\mathrm{NPV}_{\mathrm{CO}_{2}}\right)$. In their case study, data from the Norwegian NFI was used but the information was aggregated to "type-stands". The aim was to explore the production possibility frontier for $\mathrm{NPV}_{\mathrm{NOK}}$ and $\mathrm{NPV}_{\mathrm{CO} 2}$.

We present an optimization model for performing analyses at a local to regional (subnational) level of carbon sequestration in forest biomass and forest products. The model includes the economic value of timber production and carbon sequestration and gives information on the amount of timber produced, the state of the standing forest, the carbon sequestrated and on forest biofuel as substitute for fossil fuel. The model has some similarities to the model presented by Hoen and Sohlberg (1994). Our objective was to develop a model by which local effects also can be explored as well as a model that can handle high resolution data of the tree cover for detailed analyses of timber and forest biofuel production and carbon sequestration. Therefore, the model was developed for handling sample plot and individual tree data from the Swedish NFI and was based on an empirical growth function for individual trees. Geographically explicit plot locations were used which enabled accurate calculation of transportation costs as well as the exploration of local level effects on timber production and carbon sequestration. As the conditions for forestry sometimes vary heavily within Swedish regions due to site conditions and transportation distances, the possibility of exploring local effects are important. The effect on timber production by adding a value to carbon sequestration was explored by varying the latter value in the analysis. As it is urgent to explore such effects prior to any incentive policy suggestions, we did not restrict the timber production level to the level currently used in the case study region. In the following sections, we describe our stated problem and present the model, followed by a case study performed in a region in northern Sweden based on NFI sample plots. In the last section a discussion of the model and the results from the case study is presented.

\section{Problem description}

\subsection{Problem statement}

The objective of the problem we present was to maximize the net present value of wood production and carbon sequestration, including timber harvesting, extraction of harvest residues for biofuel production, transportation costs for timber and biofuel, value of carbon fixation, and the estimated cost of emission of $\mathrm{CO}_{2}$ from forest products. Constraints were included to ensure an even flow of harvest over time and a minimum ending inventory. The change in timber flow between succeeding 5 -year periods in Sweden has in average been less than one percent in the last 60 years (Anonymous, 2004). The optimization problem was then to identify how each of the treatment units included should be managed over time so that this overall objective was optimized. Management systems considered were even-aged management and programmes with no management. A management programme is a complete description over time of activities, states and outputs for a treatment unit, and a "first programme" starts from the beginning of the planning horizon. A "replacement programme" is a programme that succeeds a clear-cut of a first programme. For even-aged management, this replacement programme is assumed to be repeated in perpetuity, where each rotation starts with a planting. As alternatives to even-aged management, programmes with no management after the first planting were included. Such a programme assumes that a steady-state is reached after 100 years of no harvesting. Programmes with no management are also included in the "first programme". 


\subsection{Model type}

The problem was formulated as a linear programming problem of a type that can be considered a mixture of a model I and a model II formulation (Johnson and Scheurman, 1977). In brief, in a model I, treatment units are kept as discrete units throughout the entire planning horizon, and therefore spatial integrity can be preserved. In a model II, on the other hand, the developments under different management regimes are only projected until the time for final felling and the following regeneration. Then, in each time period, clear-cut areas are grouped with respect to some criteria and transferred to new treatment units, in a many-to-one correspondence. As a consequence, spatial information is lost after the time for clear-cut, which excludes this as an option for our study.

The model we present has the model I property that treatment units are kept as discrete units throughout the planning horizon. However, it has model II properties in the sense that areas that are clear-cut in the same period are grouped into new regeneration programmes. However, this is done in a one-to-one correspondence, so that spatial integrity is preserved. This means that a regeneration programme is specific for a unique treatment unit so that there is no grouping over different treatment units, only over different management alternatives for the same treatment unit. The reason for choosing this kind of model has to do with the stand management model used to generate alternatives, which simply makes it convenient to link replacement programmes in this way, since it simulates stand development only until the time for clear-cutting (or until the last planning period) and then stops. The stand management model then generates replacement programmes separately from the first programmes. Also, the number of decision variables is smaller than with a traditional model I.

\subsection{Mathematical formulation}

In the following, variables denoted by capital letters are global accounting variables. These are totals of outputs or states of the treatment units. Decision variables and their coefficients are denoted by small letters. We define the tuples $(i, j)$, and $(i, k, l)$, where $i$ denotes a treatment unit, $j$ a first programme alternative, $k$ a replacement programme alternative, and $l$ the establishment period for such an alternative.

The objective function $(Z$ ) of our optimization problem can be written as

$$
\text { Maximize } Z=N P V^{\text {wood }}+N P V^{\text {biofuel }}+P V^{C \text {-storage }}-P V^{\text {transport }}-P V^{C \text {-emission }}
$$

where NPV wood is the net present value of timber and pulpwood production, including deduction of silvicultural costs, NPV ${ }^{\text {biofuel }}$ the net present value from extracted harvest residues (for biofuel), including transportation costs, $\mathrm{PV}^{\mathrm{C}-\mathrm{s} t \mathrm{rag} e}$ the present value of carbon storage, $\mathrm{PV}^{\text {tansport }}$ the present value of transportation costs for timber and pulpwood, and $\mathrm{PV}^{\mathrm{C}-\mathrm{emision}}$ is the present value of the cost of $\mathrm{CO}_{2}$ emissions from products.

The problem is subject to a set of constraints (see below). Each term of the objective function is a global accounting variable, and for each such variable, at least one accounting row must be written. In order to minimize the size of the coefficient matrix, a more condensed formulation was chosen. In this, all the values associated with a certain treatment unit programme are summed into one single decision variable coefficient. This is possible because the coefficients for different decision variables are independent. With the decision variables denoted by $x_{i j}$ and $y_{i k l}$ the objective function is then reformulated to

$$
\text { Maximize } \quad Z=\sum_{i \in I} \sum_{j \in J_{i}} w_{i j} x_{i j}+\sum_{i \in I} \sum_{k \in K_{i}} \sum_{l=1}^{N} \delta(l) w_{i k l} y_{i k l}
$$

where $x_{i j}$ is the proportion of the area of treatment unit $i$ that is managed according to first programme alternative $j, y_{i k l}$ the proportion of the area of treatment unit $i$ that is clear-cut in period $l$ and thereafter managed according to replacement programme alternative $k, w_{i j}$ the value of the first programme of treatment unit $i$ when managed with alternative $j, w_{i k l}$ the value of the replacement programme of unit $i$ 
that is clear-cut in period $l$ and thereafter managed with alternative $k, N$ the number of time periods, $\delta(l)$ the discount factor for period $l,\left(=\frac{1}{(1+r)^{5(l-1)}}\right), r$ the annual discount rate, $I$ the set of all treatment units, $J_{i}$ the set of first programme alternatives for treatment unit $i$, and $K_{i}$ is the set of replacement programme alternatives for treatment unit $i$.

The calculation of $w_{i j}$ and $w_{i k l}$ will be elaborated in formulae (9) and (10).

The problem was subject to the following sets of constraints:

$$
\begin{aligned}
& V(N) \geq V(1) \\
& H(t+1) \geq(1-\xi) H(t), t=1, \ldots, N-1 \\
& \mathrm{H}(\mathrm{t}+1) \geq(1+\xi) \mathrm{H}(\mathrm{t}) \\
& \sum_{j=1}^{n_{i}} x_{i j}=1, \quad \forall i \in I \\
& \sum_{j \in J_{i l}} x_{i j}-\sum_{k=1}^{K} y_{i k l}=0 \quad \forall i, l \in T_{i} \\
& x_{i j} \geq 0 \quad \forall(i, j) \\
& y_{i k l} \geq 0 \quad \forall(i, k, l)
\end{aligned}
$$

where $V(t)$ is the volume after harvest in period $t, H(t)$ the harvested volume in period $t, \xi$ the allowable variation in harvest levels between two periods, given as the proportion of harvest level, e.g., 0.01 corresponds to $1 \%$ variation, $J_{i l}$ the set of first generation alternatives for treatment unit $i$ that involves clear-cutting in period $l$, and $T_{i}$ is the set of possible clear-cut periods for treatment unit $i$ as given by the available first generation alternatives.

Restriction (3) is to prevent a declining trend in standing volume. Restriction (4) is to simulate an even flow of harvest volumes over time. Area restrictions (5) ensure that all the area that a treatment unit represents is assigned a management programme alternative. A treatment unit can be assigned more than one management programme, meaning that different parts of the area that the unit represent are assigned different programmes. Restriction set (6) links those alternatives for a treatment unit that are clear-cut in the same period $(l)$ with one or more replacement programmes $\left(y_{i k}\right)$.

The coefficients $w_{i j}$ and $w_{i k l}$ in the reformulated objective function (2) are sums of values generated by a stand management simulator (see section 2.4). Each coefficient corresponds to a term in (1). For $w_{i j}$, we have

$$
w_{i j}=N P V_{i j}^{\text {wood }}+N P V_{i j}^{\text {biofuel }}+P V_{i j}^{C-\text { storage }}-P V_{i j}^{\text {transport }}-P V_{i j}^{C-\text { emission }}
$$

where $N P V_{i j}^{\text {wood }}$ is the net present value of timber and pulpwood production, including revenues and costs of all forestry operations (except biofuel harvesting) when treating unit $i$ with alternative $j$, $N P V_{i j}^{\text {bifiel }}$ the net present value from biofuel harvesting including deduction of fixed and distancedependent costs when treating unit $i$ with alternative $j, P V_{i j}^{\text {C-storga }}$ the present value of carbon sequestration when treating unit $i$ with alternative $j, P V_{i j}^{\text {transpor }}$ the present value of costs for transportation of timber and pulpwood from treatment unit $i$ to industries when managed according to alternative $j$, and $P V_{i j}^{C-\text { cenisision }}$ is the valued present cost of carbon emission from processed forest products when treating unit $\underline{i}$ with alternative $j$. 
The net present value of a replacement programme is calculated similarly to that of a first programme, with the difference that it must be corrected for two facts. Firstly, the value of a replacement programme refers to the time of establishment, and must therefore be discounted to the start of the planning period. This is why the discount factor $\delta(t)$ is inserted in (2). Secondly, the computation of $w_{i k l}$ for an even-aged management programme represents a perpetual series of rotations. Therefore, for even-aged alternatives, we must add a repeat factor for a geometric series:

$\alpha_{i k l}=\frac{1}{1-(1+r)^{-\lambda(i, k, l)}}$

where $\lambda(i, k, l)$ is the rotation length in years. Then, for even-aged programmes, we defined a modified version of (9) as follows.

$w_{i k l}=\alpha_{i k l}\left[N P V_{i k l}^{\text {wood }}+N P V_{i k l}^{\text {biofuel }}+P V_{i k l}^{C-\text { storage }}-P V_{i k l}^{\text {transport }}-P V_{i k l}^{C-e m i s s i o n}\right]$

The first term, or possibly the two first terms, makes up what is usually referred to as the soil expectation value $(S E V)$, but here we extend the $S E V$ to include all terms in (10). For replacement programmes with no management except planting, we have

$w_{i k l}=N P V_{i k l}^{\text {wood }}+P V_{i k l}^{C-\text { storage }}$

where $N P V_{i k l}^{\text {wood }}$ in this case only includes possible costs for establishment (planting and precommercial thinning) for treatment unit $i$ if managed according to replacement programme $k$ (per area unit). Since there will be no harvest activities after establishment, all other components are zero, except the value of carbon sequestration.

A replacement programme refers to an infinite time horizon. Since a first programme that involves clear-cutting is linked to a replacement programme, an infinite time horizon is taken into account when solving (2), and implicitly all future values are included. On the other hand, the value of a management programme that refers to unmanaged conditions does not include values that fall out in periods succeeding the last planning period. We solved this problem by assuming that a steady state is reached after the last period. Then terminal values are computed as perpetual series of periodic values. The only value to include is net carbon sequestration since there are no harvest activities taking place under these programme alternatives (and consequently no transportation, no biofuel extraction and no emissions originating from harvested products).

\subsection{Generation of treatment programme alternatives}

\subsubsection{Management programmes}

The simulations of the forest development were made by an optimizing stand-level management model presented by Wikström and Eriksson (2000) and Wikström (2001). The stand management planning problem solved with this model is to determine, simultaneously, harvest periods and what trees to harvest in these periods. This model consists mainly of an optimization programme that works in conjunction with a growth-and-yield simulator. The optimization programme generates repeated proposals for management in an iterative search process guided by Tabu search, and in each iteration, the growth model is called and the management proposal is evaluated by an objective function routine.

For each treatment unit, i.e. plot, the model was run three times under different objectives, (a) maximize net present value, (NPV), and (b) maximize NPV minus transportation cost. Constraints were included to (1) control that thinning grades did not exceed $30 \%$ of the stand basal area, (2) that 
ending inventory was at least $100 \mathrm{~m}^{3}$ per hectare at the time for final harvest, and (3) that programmes did not violate the lowest age for clear-cutting as imposed by the Swedish Forest Act (Anonymous, 1995). In addition, one programme (c) with no harvest activities was generated to provide an unmanaged alternative. For each of problems (a) and (b), the 10 best solutions were stored to be used as management programme alternatives in the regional analysis. A solution is defined by a unique combination of harvest periods, and sometimes fewer than 10 feasible solutions were found. Therefore, the total number of alternative management programmes for a plot was often smaller than the maximum number of 21 .

The replacement programmes were generated in the same way, but for even-aged management, which was solved to maximize the value of a perpetual series of rotations. When writing the LP matrix, copies of these alternatives were made, one for each establishment period possible. This means that identical programme alternatives are available for different establishment periods.

\subsubsection{Growth-and-yield projections}

The individual-tree growth function of Söderberg (1986) was used to predict five-year basal area growth of individual trees with a mean diameter of at least $4 \mathrm{~cm}$ (dbh). Response to thinning was then predicted with the model of Jonsson (1980) as a function of thinning intensity. Natural mortality was assessed by the functions of Fridman and Ståhl (2001). The height curves of Söderberg (1992) were used to calculate tree height. Tree volume was then assessed according to Brandel (1990). At "young forest plots" (mean height less than $7 \mathrm{~m}$ ) were tree heights projected according to Nyström (2000, p. 14, Table 5) until the mean height was $7 \mathrm{~m}$. A diameter was then assigned to the trees according to Elfving (1982, p. 65, Table 8), after which the growth functions of Söderberg were used. Initial states for the replacement programmes were simulated by selecting plots with young stems from the HUGIN young forest survey database (Elfving, 1982).

In order to assess harvest revenues from individual trees, the stem form was calculated with the taper curves of Edgren and Nylinder (1949), then theoretical bucking according to Näsberg (1985) was applied. Since the theoretical bucking is computationally demanding, cubic spline functions were generated from a number of generated tree-value pairs to approximate the value of a tree as a function of its diameter (cf. Wikström and Eriksson, 2000).

\subsubsection{Biomass estimations}

For estimation and prediction of forest biomass contents, functions by Petersson (1999) were used. These functions include functions to estimate the biomass content (dry weight) of stems, branches, needles, stumps and coarser roots. Soil carbon was not included because of a lack of suitable models. The decay of above and below ground tree parts was assessed with the function presented by Harmon et al. (2000). The below ground tree parts was assumed to decay in the same manner as the above ground tree parts. The biomass change in every period was calculated as the sum of the growth of living biomass minus the decay of dead biomass, harvested wood and natural mortality.

\subsubsection{Extraction of harvest residues for biofuel}

The extraction of forest biofuels is assumed to include $75 \%$ of branches and tree tops and $25 \%$ of the needles (Anonymous, 2001). The extraction of harvest residues for use as biofuel was only simulated at sites with soils that are not too poor, in this case on more fertile sites than lichen types, as recommended by the Forestry Board (Anonymous, 2001).

\subsubsection{Valuation of carbon fixation and emissions}

To assess the carbon content of trees, a fixed proportion of $49 \%$ of the dry weight biomass was used in the calculations (Ståhl et al., 2004). A positive carbon change was then multiplied by a carbon price to achieve an economic value for carbon sequestration. By varying the price on carbon, different policies can be evaluated. The carbon price was applied for the whole planning horizon and was also fixed for the whole planning horizon.

Carbon emissions from wood products were calculated in the same way as in Karjalainen et al. (1994) and Liski et al. (2001). Distribution among forest products was set according to Swedish 
conditions (Warensjö, 1997). The emission rates were calculated for timber and pulpwood. Carbon in products disposed to landfills was assumed to be released to the atmosphere immediately. The emissions were charged and discounted to the start of the planning horizon $\left(P V_{I j}^{\text {Cermision }}\right)$. The emission factors for timber and pulpwood are discounted compound values of the fraction of carbon emitted from ageing products produced after the time for harvest.

\subsubsection{Transportation costs}

The transportation cost was $12.28+0.38 \underline{d}$ SEK $^{1}$ per cubic metre and was a weighted mean for both truck and railway transportation according to Arvidsson and Holmgren (1999) and Statistical Yearbook (Anonymous, 2002). The transportation distance (d) was calculated as a function of a straight line and a standard correction function to estimate actual transportation distances (Anonymous, 1992).

In the model, the timber was transported to local sawmills, and the pulpwood to the (one) pulp mill at the coast. The extracted harvest residues were supposed to be transported to the nearest town with more than 2000 inhabitants. The transportation cost for harvest residues was $64.8+1.296 d$ SEK tonne ${ }^{-1}$ (Anonymous, 1993; Andersson and Nordén, 1996). Carbon emissions from transportation were not included.

\section{Case study}

The model was tested on a dataset representing a large region in Sweden with varying conditions for forestry. The reason for choosing the specific region was twofold: firstly, we wanted to be sure that the model could handle large datasets; and secondly, we expected that using an area with varying conditions would lead to divergent results for different parts of the region.

The region chosen for the study was the county of Västerbotten, which is located in the northern part of Sweden (Figure 1) in the boreal forest region. The county is rich in forest with a gradient in productivity, with the highest productivity at the coast, declining to the west. The forest consists mainly of conifers. Many of the industries are located in the coastal region, leading to high transportation costs for timber and pulpwood harvested in the western part of the region. Therefore, conditions for forestry vary depending on the location within the region.

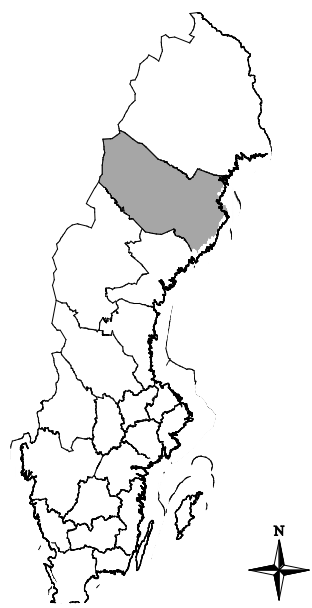

Figure 1. Sweden and the county of Västerbotten (shaded area).

Detailed forest data for Västerbotten county was available through the National Forest Inventory (NFI). (Ranneby et al., 1987). In this study, 3308 plots were used that are located on productive (site productivity $\geq 1 \mathrm{~m}^{3} \mathrm{ha}^{-1} \mathrm{yr}^{-1}$ ) and non-protected forestland that had been inventoried in the period 1996-2000. The total area of the forestland represented by these plots was 3.2 million hectares. The prices used for timber, pulpwood and forest biofuel were the actual local prices. The discount rate was set to $3 \%$, and the harvest levels were allowed to drop or rise by $1 \%$ from the previous period.

\footnotetext{
1 SEK=0.13 USD (23 March 2004)
} 


\subsection{Results}

The Swedish $\mathrm{CO}_{2}$ tax in year 2002 was 630 SEK tonne ${ }^{-1} \mathrm{CO}_{2}$. This corresponds to a carbon price of 2308 SEK tonne $e^{-1}$. When we entered this value in the model, no harvest at all occurred. Therefore a set of lower carbon prices were tested, ranging from zero to 1200 SEK tonne ${ }^{-1}$. In the following, only carbon stored in the forest (living and dead biomass excluding soil) is presented. Carbon stored in products affected the solution by reducing the total net present value when the products deteriorate and carbon was released to the atmosphere. The resulting quantity stored in products over time is, however, not presented.

The results show that an increase in carbon storage reduces the NPV of the harvest (Figure 2). The decrease in NPV is moderate at low carbon prices but drops more quickly above about s200 SEK tonne ${ }^{-1}$. The decrease in NPV is caused by lowered harvest levels (Figure 3). The mean annual harvest level given a zero carbon price was 5.43 million $\mathrm{m}^{3}$ per year. A zero harvest level was reached at a carbon price somewhat below 1000 SEK tonne $^{-1}$; i.e., far below a carbon price corresponding to the present Swedish $\mathrm{CO}_{2}$ tax $\left(2308\right.$ SEK tonne $\left.{ }^{-1} \mathrm{C}\right)$. The average carbon increase for the entire region varies between 1.48 and 2.05 million tonnes per year given the minimum (zero) and maximum (2308 SEK tonne ${ }^{-1}$ ) carbon price applied. This corresponds to an average net carbon sequestration per year of $0.46-0.64$ tonnes per hectare. The total carbon storage in living and dead forest biomass increased over time (Figure 4). The total carbon storage was increasing at a slower rate at the end of the planning horizon, which implies that the carbon flux into the forest was decreasing

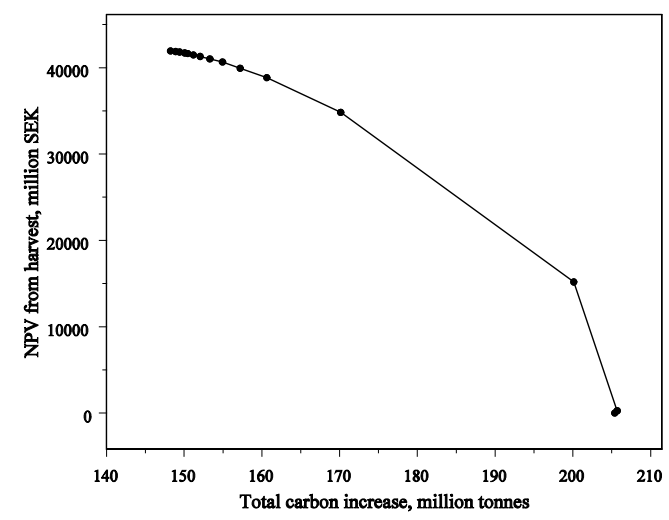

Figure 2. Trade off between NPV of harvest and total increase in forest carbon storage for a 100 -year period for carbon prices between zero (upper-left point) and 2308 (lower-right point) SEK tonne $e^{-1}$.

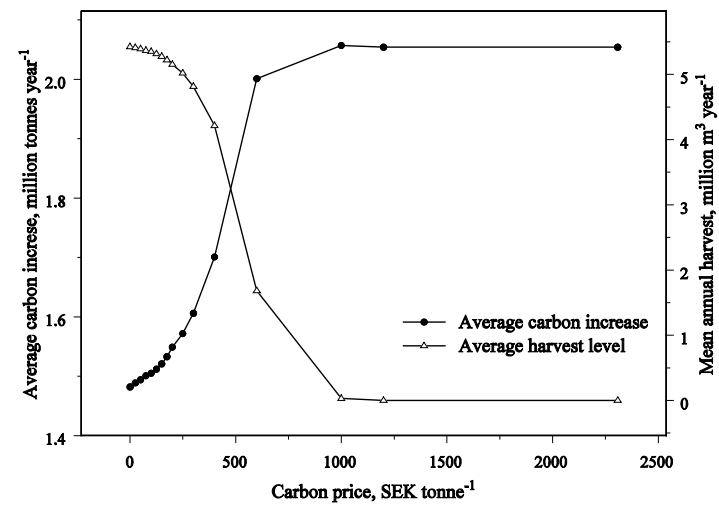

Figure 3. Average increase of stored forest carbon and mean annual harvest for a 100 year period for carbon prices between zero and 2308 SEK tonne ${ }^{-1}$.

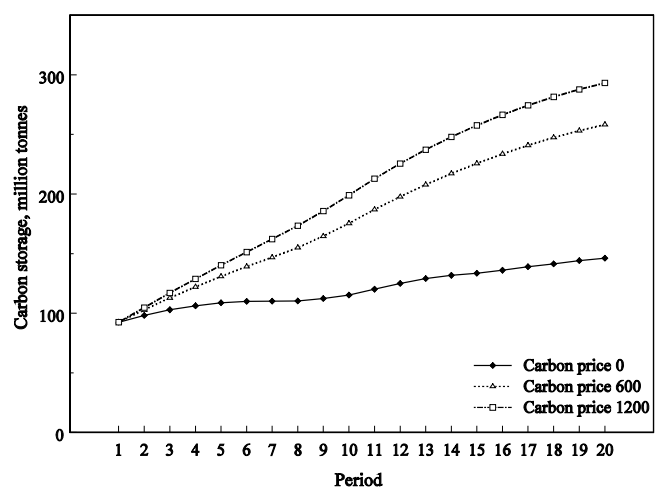

Figure 4. Total carbon storage (million tonnes) in living and dead forest biomass in each five year period for carbon prices zero, 600 and 1200 SEK tonne $e^{-1}$. 
When no carbon price exists (i.e., management as usual) the average harvest volume $\left(\mathrm{m}^{3} \mathrm{year}^{-1} \mathrm{ha}^{-1}\right)$ varied depending on the location within the region (Figure 5a). When we applied a carbon price of 400 SEK tonne ${ }^{-1}$, the harvest levels for the whole region decreased (as shown in Figure 3 ), but the decrease was greater in the western parts (Figure $5 \mathrm{~b}$ ).

The average net carbon sequestration (tonnes carbon year ${ }^{-1} \mathrm{ha}^{-1}$ ) given a zero carbon price (Figure 5c) shows the same pattern as the harvest levels; i.e., highest sequestration in the coastal region. This is a result of the gradient in productivity. The difference in average net carbon sequestration between the scenario with a zero carbon price and a carbon price of 400 SEK tonne ${ }^{-1}$ (Figure $5 \mathrm{~d}$ ) is positive for all regions, but the pattern from the previous three maps is gone. Some areas of the eastern part of the region have as high an increase as the western parts. This is probably an effect of the gradient in productivity - when the productivity is high it is possible to produce both timber and carbon storage.
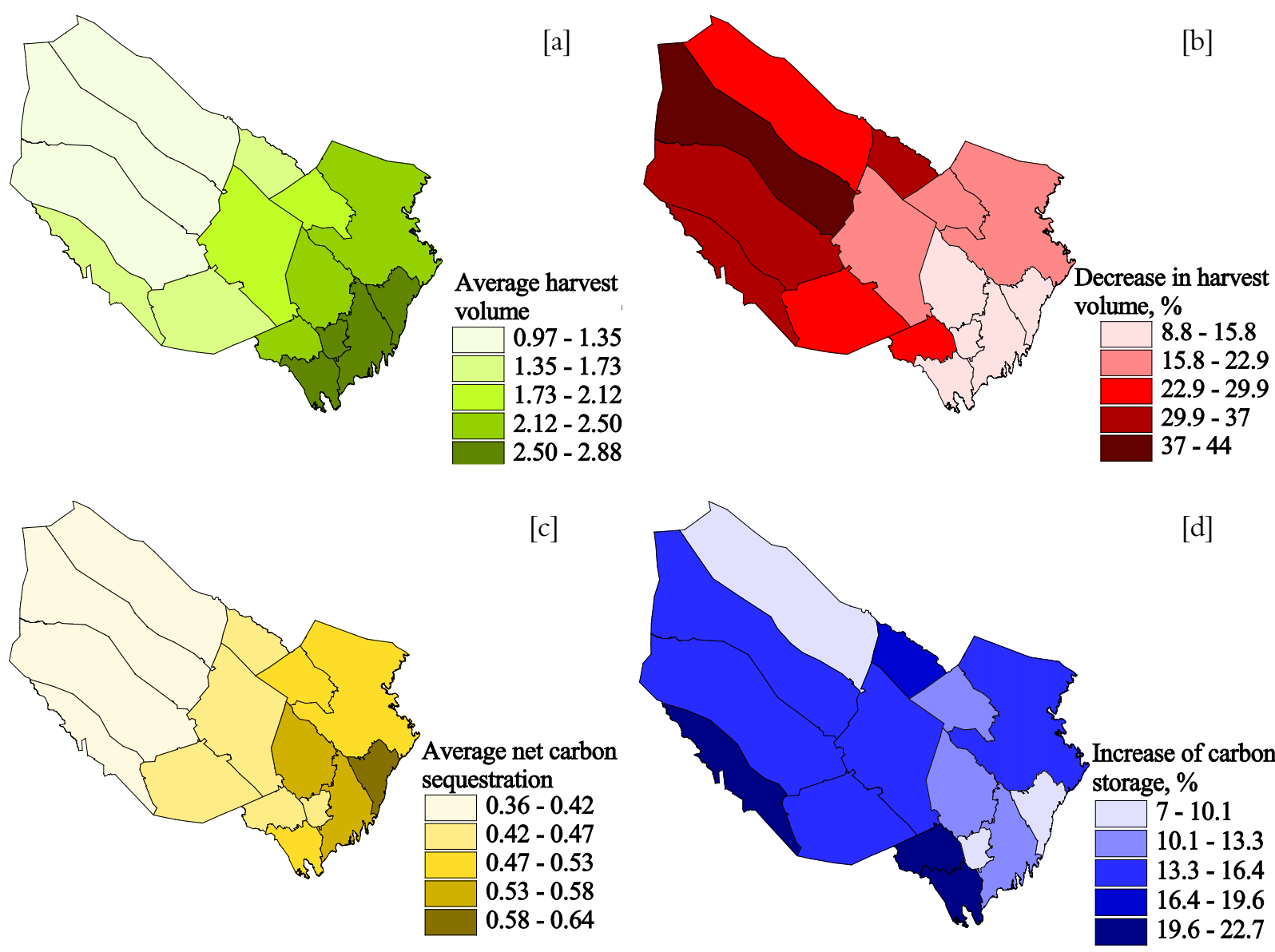

Figure 5. Upper row: average harvest level $\left(\mathrm{m}^{3} \mathrm{year}^{-1} \mathrm{ha}^{-1}\right)$ when no carbon price was applied [a] and decrease in average harvest level (per cent) when a carbon price of 400 SEK tonne ${ }^{-1}$ was applied [b]. Bottom row: average net carbon storage (tonne carbon year ${ }^{-1}$ and $\mathrm{ha}^{-1}$ ) for no carbon price $[\mathrm{c}$ ] and increase in carbon sequestration (per cent) when a carbon price of 400 SEK tonne ${ }^{-1}$ was applied $[\mathrm{d}]$.

\section{Discussion}

The results from the case study show that the model produces realistic results. The harvest levels are in line with the actual harvest levels in the region (Anonymous, 2004). A carbon increase of $0.46-0.64$ tonnes carbon year ${ }^{-1} \mathrm{ha}^{-1}$ is not unrealistic. Previously reported values from Sweden are in the range of $0.22-0.44$ tonnes carbon year ${ }^{-1} \mathrm{ha}^{-1}$ (Ståhl et al., 2004). These values are the actual net increase in the last decade. Note that in this case study, only the carbon increase in living and dead trees is presented in the results, although the carbon in products is included in the economic calculations.

The growth model used is empirical and not designed to handle effects caused by a changing climate. For that purpose, a process-based growth model, where growth is affected by climate, is 
needed. Another possible solution is to adjust the growth in an empirical model. As direct measurements on growth in a changing climate are difficult, the adjustments can be based on calculations from a process-based model. Other future extensions could include management regimes other than even-aged management; for example, the shelter-wood system or selective cutting.

The LP model presented can handle large problems and still preserve a high degree of detail at a stand level. The model also includes factors such as carbon in products (and emissions from these products) and production of forest biofuel. Thinning regimes and the age structure of the forest can also be carefully examined with the model.

The high rate of detail in the model requires a detailed and comprehensive forest information dataset. Such information is provided by the Swedish NFI. The lack of this information in other countries or regions will, of course, hamper the implementation of the model. High resolution data doesn't automatically mean that the data is of high quality, but high resolution gives the possibility to perform more analyses without the need to use simplifications. In general, the more correct the present state is described, the better the prediction will be (Kangas, 1998; Nyström and Ståhl, 2001). The NFI data in our study is an objective sample of the forest in the region.

In the case study, we applied a carbon payment regime. It involves a subsidy paid when carbon storage is increased. When the forest is harvested the timber volume is transformed into two different use classes (pulpwood and sawn timber). Emissions from the use classes are then taxed as the products deteriorate. Because of the discounting effect there is a gain between the time of increase in carbon storage and the time of emission. The longer the time, the larger the gain. Thus, sawn timber has an advantage compared to pulpwood.

The data set used for the case study area lacked information on the amount of dead wood. The change in biomass (living and dead) between period 1 and period 2 is therefore overestimated, because the change in dead wood increases from zero to the amount formed by period 2. In reality the increase is less as an initial amount of dead wood does exist. There are two ways to handle this problem. Dead wood on the plots could be simulated, or the problem can be simply neglected. We choose the latter approach because simulation of dead wood into all the plots would be time demanding and include elements of uncertainty that are beyond the scope of this study. According to Fridman and Walheim (2000), the amount of dead wood in the region is 5.6-9.7 $\mathrm{m}^{3} \mathrm{ha}^{-1}$. Lämås and Fries (1994) found that the amount of dead wood was $1.74 \mathrm{~m}^{3} \mathrm{ha}^{-1}$ in a large forest area (8600 ha) in Västerbotten. It is obvious that there is a large local variation in the amount of dead wood in the studied area.

We can conclude from our case study that imposition of a carbon price affects both harvest levels and carbon storage. The results presented here are quite sparse, but the aim of the study was to create this optimizing model for analysis of carbon storage and timber production. In forthcoming studies, we will present more detailed results regarding forest biofuel, difference in management regimes and the effect on management by different payment regimes, for example.

\section{Acknowledgements}

The study was financially supported by the Kempe foundations and the Heureka Research Programme at the Faculty of Forest Sciences at SLU (Swedish University of Agricultural Sciences). 


\section{References}

Adams, D.M., Alig, R.J., McCarl, B.A., Callaway, J.M., Winnet, S., 1999. Minimum cost strategies for sequestering carbon in forests. Land Economics 75, 360-374.

Ågren, G.I. and Hyvönen, R., 2003. Changes in carbon stores in Swedish forest soils due to increased biomass harvest and increased temperatures analysed with a semi-empirical model. For. Ecol. Manage. 174, 25-37.

Andersson, G. and Nordén, B., 1996. Balning av trädrester - En systemanalys. SkogForsk, Uppsala. (in Swedish).

Anonymous, 1992. Skogspolitiken inför 2000-talet: huvudbetänkande. Bilagor II. SOU 1992:76. Stockholm. (in Swedish).

Anonymous, 1993. Virkesbalanser meddelande 2:1993. National Board of Forestry. Jönköping. (in Swedish).

Anonymous, 1995. Skogsvårdslagen. National Board of Forestry, Jönköping. (in Swedish).

Anonymous, 2000. Land use, land-use change, and forestry: special report of the Intergovernmental Panel on Climate Change. Cambridge University Press, Cambridge.

Anonymous, 2001. Rekommendationer vid uttag av skogsbränsle och kompensationsgödsling. Report 2:2001. National Board of Forestry, Jönköping. (In Swedish).

Anonymous, 2002. Skogsstatistisk årsbok 2002. National Board of Forestry, Jönköping. (in Swedish with English summary).

Anonymous, 2003. European Parliament. Directive 2003/87/EC of the European Parliament and of the Council of 13

October 2003 establishing a scheme for greenhouse gas emission allowance trading within the Community and amending Council Directive 96/61/EC.

Anonymous, 2004. Skogsstatistisk årsbok 2004. National Board of Forestry, Jönköping. (in Swedish with English summary)

Arvidsson, P.-Å. and Holmgren M., 1999. Modell för beräkning av kostnader orsakade av bristande bärighet i vägnätet. SkogForsk, Uppsala. (in Swedish).

Brandel, G., 1990. Volume functions for individual trees; Scots pine (Pinus sylvestris), Norway spruce (Picea abies) and birch (Betula pendula and Betula pubescens). Report 26:1990. Dept. of Forest Yield Res., Swedish Univ. of Agric. Sci., Garpenberg. (in Swedish, with English summary).

Cannell, M.G.R., 2003. Carbon sequestration and biomass energy offset: theoretical, potential and achivable capacities globally, in Europe and the UK. Biomass Bioenerg. 24, 97-116.

Creedy, J. and Wurzbacher, A.D., 2001. The economic value of a forested cathcment with timber, water and carbon sequestration benefits. Ecol. Econ. 38, 71-83.

Edgren, W. and Nylinder, P., 1949. Functions and tables for computing taper and form quotient inside bark for pine and spruce in northern and Sweden, Meddelande från Statens skogforskningsinstitut. Stockholm. (in Swedish, with English summary).

Elfving, B., 1982. HUGIN's ungskogstaxering 1976-1979. Swedish Univ. of Agric. Sci., Umeå. (in Swedish).

Field, B.C., 2001. Natural Resource Economics - An Introduction. McGraw-Hill, New York.

Fridman, J. and Ståhl, G., 2001. A three-step approach for modelling tree mortality in Swedish forests. Scand. J. Forest Res. $16,455-466$.

Fridman, J. and Walheim, M., 2000. Amount, structure, and dynamics of dead wood on managed forestland in Sweden. For. Ecol. Manage. 131, 23-36.

Harmon, M. E., Krankina, O. N., Sexton, J., 2000. Decomposition vectors: a new approach to estimate woody detritus decomposition dynamics. Can. J. Forest Res. 30, 76-84.

Hoen, H.F. and Solberg, B., 1994. Potential and economic efficiency of carbon sequestration in forest biomass through silvicultural management. Forest Sci. 40, 429-451.

Hoen, H.F., 1994. The Faustmann rotation in the precense of a positive CO2 price. In: Helles, F. and Linddal, M. (Eds.), Scand for econ., Gilleleje, Denmark. pp 278-287.

Jiang, H., Apps, M.J., Peng, C., Zhang, Y., Liu, J., 2002. Modelling the influence of harvesting on Chinese boreal forest carbon dynamics. For. Ecol. Manage. 169, 65-82. 
Johnson, K.N. and Scheurman, H.L., 1977. Techniques for prescribing optimal timber harvest and investment under different objectives. Discussion and synthesis. For. Sci. 18. Forest Sci. Monograph.

Jonsson, B., 1980. Functions for long-term forecasting of the size and structure of timber yields. Report 7:1980. Dept. of Biometry and For. Manage., Swedish Univ. of Agric. Sci., Umeå. (in Swedish, with English summary).

Kangas, A.S., 1998. Effect of errors-in-variables on coefficients of a growth model and on prediction of growth. For. Ecol. Manage. 102, 203-212.

Karjalainen, T. 1996a Dynamics of the carbon flow through forest ecosystem and the potential of carbon sequestration in forests and wood products in Finland, Dissertation. Univ. of Joensuu, Joensuu.

Karjalainen, T., 1996b. The carbon sequestration potential of unmanged forest stands in Finland under changing climatic conditions. Biomass Bioenerg. 10, 313-329.

Karjalainen, T., Kellomäki, S., Pussinen, A., 1994. Role of wood-based products in absorbing atmospheric carbon. Silva Fenn. 28, 67-80.

Kimmins, J.P., Mailly, D., Seely, B., 1999. Modelling forest ecosystem net primary production: the hybrid simulation approach used in FORECAST. Ecol. Model. 122, 195-224.

Krankina, O.N., Harmon, M.E., Winjum, J.K., 1996. Carbon storage and sequestration in the Russian forest sector. Ambio 25, 284-288.

Lämås, T. and Fries, C., 1994. An integrated forest inventory in a managed North-Swedish forest landscape for estimating growing stock and coarse woody debris. In: The Monte Verita Conference on Forest Survey Design: 'Simplicity versus Efficiency' and the Assessment of Non-Timber Resources, May 2-7, 1994, Monte Verita, Switzerland. pp 296-311.

Lasch, P., Lindner, M., Ebert, B., Flechsig, M., Gerstengarbe, F.-W., Suckow, F., Werner, P.C., 1999. Regional impact analysis of climate change on natural and managed forests in the Federal State of Brandenburg, Germany. Environ. Model. Assess. 4, 273-286.

Lasch, P., Lindner, M., Erhard, M., Suckow, F., Wenzel, A., 2002. Regional impact assessment on forest structure and functions under climate change - the Brandenburg case study. For. Ecol. Manage. 162, 73-86.

Liski, J., Pussinen, A., Pingoud, K., Mäkipää, R., Karjalainen, T., 2001. Which rotation length is favourable to carbon sequestration? Can. J. Forest Res. 31, 2004-2013.

Masera, O.R., Garza-Caligaris, J.F., Kanninen, M., Karjalainen, T., Liski, J., Nabuurs, G.J., Pussinen, A., de Jong, B.H.J., Mohren, G.M.J., 2003. Modeling carbon sequestation in afforestration, agroforestry and forest management projects: the CO2FIX V.2 approach. Ecol. Model. 164, 177-199.

Minkkinen, K., Laine, J., Hökkä, H., 2001. Tree stand development and carbon sequestration in drained peatland stands in Finland - a simulation study. Silva Fenn. 35, 55-69.

Murray, B.C., McCarl, B.A., Lee, H.C., 2004. Estimating leakage from forest carbon sequestration programs. Land Economics 80, 109-124.

Myneni, R.B., Dong, J., Tucker, C.J., Kaufmann, R.K., Kauppi, P.E., Liski, J., Zhou, L., Alexeyev, V., Hughes, M.K., 2001. A large carbon sink in the woody biomass of Northern forests. PNAS, 14784-14789.

Nabuurs, G.J., Garza-Caligaris, J.F., Kanninen, M., Karjalainen, T., Lapveteläinen, T., Liski, J., Masera, O.R., Mohren, G.M.J., Pussinen, A., Schelhass, 2002. CO2FIX V.2.0. Manual of a model for quantifying carbon sequestration in forest ecosystem and wood products. Alterra report 445:2002, Netherlands.

Näsberg, M. 1985 Matchematical programming models for optimal log bucking. Linköping studies in science and technology. Dissertation, Linköping University, Linköping.

Nyström, K. and Ståhl, G., 2001. Forecasting probability distributions of forest yield allowing for a Bayesian approach to management planning. Silva Fenn. 35, 185-201.

Nyström, K., 2000. Funktioner för att skatta höjdtillväxten i ungskog. Report 68:2000. Dept. of For. Resource Management and Geomatics, Swedish Univ. of Agric. Sci., Umeå. (in Swedish).

Parton, W.J., Schimel, D.S., Cole, C.V., Ojima, D.S., 1987. Analysis of factors controlling soil organic matter levels in great Plains grasslands. Soil Sci. Soc. Amer. J. 51, 1173-1179.

Petersson, H., 1999. Biomassafunktioner för trädfunktioner av tall, gran och björk i Sverige. Arbetsrapport 59. Dept. of For. Resource Management and Geomatics, Swedish Univ. of Agric. Sci., Umeå. (in Swedish)

Prentice, I.C. and Leemans, R., 1990. Patterns and process and the dynamics of forest structure: a simulation approach. J. Ecol. 78, 340-355.

Prentice, I.C., Sykes, M.T., Cramer, W., 1993. A simulation model for the transient effects of climate change on forest landscapes. Ecol. Model. 65, 51-70.

Pussinen, A., Karjalainen, T., Mäkipää, R., Valsta, L., Kellomäki, S., 2002. Forest carbon sequestration and harvests in Scots pine stand under different climate and nitrogen deposition scenarios. For. Ecol. Manage. 158, 103-115.

Ranneby, B., Cruse, T., Hägglund, B., Jonasson, H., Swärd, J., 1987. Designing a new national forest survey for Sweden. Report 177:1987. Swedish Univ. of Agric. Sci., Uppsala.

Rolff, C. and Ågren, G., 1999. A model study of nitrogen limited forest growth. Ecol. Model. 118, 193-211. 
Seely, B., Kimmins, J.P., Welham, C., Scoullar, K.A., 1999. Ecosystem management models: defining stand-level sustainability exploring stand-level stewardship. J. Forest. 97, 4-10.

Seely, B., Welham, C., Kimmins, H., 2002. Carbon sequestration in a boreal forest ecosystem: results from the ecosystem simulation model, FORECAST. For. Ecol. Manage. 169, 123-135.

Söderberg, U., 1986. Functions for forecasting timber yields: increment and form height of individual trees of native tree species in Sweden. Report 14:1986. Dept. of Biometry and For. Manage., Swedish Univ. of Agric. Sci., Umeå. (in Swedish, with English summary).

Söderberg, U., 1992. Functions for forest management. Height, form height and bark thickness of individual trees. Report 52:1992. Dept. of Forest Survey, Swedish Univ. of Agric. Sci., Umeå. (in Swedish, with English Summary).

Sohngen, B. and Sedjo, R., 2000. Potential Carbon Flux from Timber Harvests and Management in the Context of a Global Timber Market. Climatic change 44, 151-172.

Song, C. and Woodcock, C.E., 2003. A regional ecosystem carbon budget model: impacts of forest age structure and landuse history. Ecol. Model. 164, 33-47.

Spinney, M., P and Prisley, S., P, 2002. Modelling the effects of forest management on carbon sequestration in a loblolly pine plantation. In: SymFor, Systems Analysis Forestry Symposium, Punta de Tralca, Chile.

Ståhl, G., Boström, B., Lindkvist, H., Lindroth, A., Nilsson, J., Olsson, M., 2004. Methodological options for quantifying changes in carbon pools in Swedish forests. Studia For. Suec. 214. Studia For. Suec. Swedish Univ. of Agric. Sci, Faculty of Forestry, Uppsala, Sweden.

Turner, D.P., Koerper, G.J., Harmon, M.E., Lee, J.J., 1995. A carbon budget for forests of the conterminous United States. Ecol. Appl. 5, 421-436.

van Kooten, G.C., Binkley, C.S., Delcourt, G., 1995. Effect of carbon taxes and subsidies on optimal forest rotation age and supply of carbon services. Am. J. Agr. Econ. 77, 365-374.

Warensjö, M., 1997. The sawmilling industry 1995, Part 1 Production and timber requirement. Report 251:1997. Department of Forest Products, Swedish Univ. of Agric. Sci., Uppsala.

Wikström, P. and Eriksson, L.-O., 2000. Solving the stand management problem under biodiversity-related considerations. For. Ecol. Manage. 126, 361-376.

Wikström, P., 2001. Effect of decision variable definition and data aggregation on a search process applied to a single-tree simulator. Can. J. Forest Res. 31, 1057-1066. 